\title{
Dentist knowledge about dental health management for disabled child at primary health service in Bandung City
}

\author{
Elvanissa Ruslan*, Arlette Suzy Puspa Pertiwi*, Sri Susilawati** \\ *Department of Pedodontic, Faculty of Dentistry Universitas Padjadjaran, Indonesia \\ **Department of Public Dental Health, Faculty of Dentistry Universitas Padjadjaran, Indonesia
}

\begin{abstract}
Introduction: Disabled children encounter physical and/or mental hindrance that interferes the normal growth and development. Children with disability have lower oral hygiene level compared to normal children, hence a thorough dental treatment for these children are very important. The Indonesia's Health Minister's Regulation number 89 in 2015 has become one of the references in performing dental treatment for the disabled children. Method: This study was a descriptive study by using questionnaire to gather the data. Results: This study showed $69.73 \%$ of the dentists at primary health service in Bandung City were aware of the government regulation about the primary health service for children with disability. Discussion: Preventive and curative efforts are necessary regarding the fact that disabled children have higher level of poor oral hygiene than normal children. The sufficient category showed that the dentists in primary health center need additional information and knowledge to identify the children with disability. Conclusion: The dentists' knowledge of the oral health service for children with disability in primary health service based on Indonesia's Health Minister's Regulation number 89 in 2015 was sufficient regarding the percentage of $69.73 \%$.
\end{abstract}

Keywords: Disabled children, The Indonesia's Health Minister's Regulation number 89 in 2015

\section{INTRODUCTION}

The number of individuals with disability in Indonesia have increased. Survey Kesehatan Nasional (National Health Survey) stated that in 2003, the percentage of the disabled individuals was $0.69 \%$, which increased in 2006 to $1.38 \%$. Although the percentage has decreased in 2009 to $0.92 \%$, it has increased again quite significantly in 2012 to $2.45 \% .^{1}$ In accordance to this, the number of disabled children that managed through the early ages have also increased..$^{1,2}$ Disabled children are children with physical, mental, health, or social disturbances. These disturbances also occurred in children with special needs. ${ }^{3,4}$

In 1976, Brown and Schodel conducted a study of 32 children with disability. The study reported that the children had poorer oral hygiene compared to normal children. This condition was one of the main risk factors of caries in disabled children.5,6 Nowadays, parents have grown aware of the importance of dental health care for disabled children, both preventive and restorative. Dentists should perform a thorough health service in order to fulfill the children's dental health needs. ${ }^{7}$ 
The first level of dental health service is performed at primary health service ${ }^{1}$, thus dentists play a role of gate-keeper as they are the first to give dental health service to society. These dentists are also expected to accentuate the preventive and promotive aspect of the dental health service. ${ }^{8}$ The Indonesia's Health Minister's Regulation number 89 in 2015 about dental and mouth health services elaborates on page 5 : the identification and characteristics of dental health, including the treatments for disabled children. The regulation could be the reference for dentists in giving dental health services for disabled children. ${ }^{1}$

\section{METHODS}

This study was a descriptive study by using a questionnaire which contents and reliability had been ratified. The questionnaires were given to the dentists in Primary health service. The population in this study was dentists assigned at primary health service in Bandung City. The samples were selected through a cluster sampling method.

In this method, the samples were selected randomly from a group of individuals that was formed naturally, for instance: a group of individuals in a certain region. ${ }^{9}$ The study was conducted at primary health service in Bandung City. Bandung City consisted of 6 regions: Bojonagara, Tegallega, Cibeunying, Karees, Gedebage, and Ujungberung. After random selection, 3 regions were chosen: Ujungberung, Bojonagara, and Cibeunying. From the 3 regions, 21 dentists were selected as subjects with the same criteria. All subjects were assigned at primary health service in Bandung City and were willing to fill the questionnaires.

\section{RESULTS}

Most of the dentists at primary health service in Bandung City (57.14\%) did not aware and have never read the regulation about dental health service (Table 1) Most dentist also did not aware about dental treatment for disable children as based on The Indonesia's Health Minister's Regulation number 89 in 2015 (Table 2). According to Table 3, all dentists answered correctly on the definition of disabled children. In contradiction, only $61.9 \%$ and $75.19 \%$ correctly answered the question of the definition of physical and mental/ intellectual disability in children.

The following results describe dentists' knowledge on classification of disabled children. $90.48 \%$ of subjects answered correctly on the classification of disabled children as developmental disturbance of the motoric nerves such as cerebral

Table 1. Dentists' awareness of the Indonesia's Health Minister's regulation number 89 in primary health service in Bandung City

\begin{tabular}{ccc}
\hline Category & Frequency & $\%$ \\
\hline Not aware and has never read & 12 & 57.14 \\
Aware but has never read & 1 & 4.76 \\
Aware and has read & 8 & 38.10 \\
Total & 21 & 100
\end{tabular}

Table 2. Dentists' knowledge about dental treatments for disabled children as based on The Indonesia's Health Minister's Regulation number 89 in 2015

\begin{tabular}{ccc}
\hline Category & Frequency & $\%$ \\
\hline Aware & 8 & 38,10 \\
Not Aware & 13 & 61,90 \\
Total & 21 & 100 \\
\hline
\end{tabular}

Table 3 Dentists' knowledge on definition of disabled children

\begin{tabular}{|c|c|c|c|}
\hline No & Definition of disabled children & Correct (\%) & Incorrect (\%) \\
\hline 1 & $\begin{array}{l}\text { Disabled children are individuals with physical and/or mental abnormality that } \\
\text { disrupt or hinder various normal activities }\end{array}$ & 100 & 0 \\
\hline 2 & $\begin{array}{l}\text { Disabled children are individuals with mental/intellectual and/or behavior ab- } \\
\text { normality }\end{array}$ & 61.90 & 38.10 \\
\hline 3 & $\begin{array}{l}\text { Mentally/intellectually disabled children are individuals with physical abnor- } \\
\text { mality that disrupts physical function such as body movements, sights, hear- } \\
\text { ing, talking ability, and chronic disease (leprosy, TBC, diabetes, hypertension, } \\
\text { stroke). }\end{array}$ & 75.19 & 23.81 \\
\hline
\end{tabular}


Table 4. Dentists' Knowledge on The Classification of Disabled Children

\begin{tabular}{clcc}
\hline No & \multicolumn{1}{c}{ Classification of disabled children } & Correct (\%) & Incorrect (\%) \\
\hline 1 & $\begin{array}{l}\text { Physical disability consisting sensory disturbance, develop- } \\
\text { mental disturbance of the motoric nerve, cerebral vascular } \\
\text { accident (VCA)/stroke, and arthritis. }\end{array}$ & 85.71 & 14.29 \\
& $\begin{array}{l}\text { Mental disability consisting deafness and hearing impair- } \\
\text { ment, also blindness and visual impairment. }\end{array}$ & 71.43 & 28.57 \\
3 & $\begin{array}{l}\text { Sensory disturbance includes developmental and growth } \\
\text { disturbance, also psychiatric disturbance. } \\
\text { Developmental disturbance of the motoric nerves includes } \\
\text { cerebral palsy and epilepsy. }\end{array}$ & 71.43 & 28.57 \\
\hline
\end{tabular}

Table 5. Dentists' knowledge on dental treatment and promotive effort for disabled children

\begin{tabular}{clcc}
\hline No & \multicolumn{1}{c}{ Dental Treatment for Disabled Children } & Correct (\%) & Incorrect (\%) \\
\hline 1 & $\begin{array}{l}\text { To perform a fair dental treatment for disabled chil- } \\
\text { dren, an integratedcollaboration between dentist, } \\
\text { inter or multidiscipline team, parents/caretakers, } \\
\text { teachers, and disabled individuals is needed. } \\
\text { Counseling is one of the promotive efforts by giving } \\
\text { the parents dental health education }\end{array}$ & 100 & 0 \\
& 100 & 0 \\
\hline
\end{tabular}

Tabel 6. Dentists' knowledge on the Oral Health Service of Children with Disability in Primary Service based on The Indonesia's Health Minister's Regulation number 89 in 2015

\begin{tabular}{|c|c|c|c|}
\hline $\begin{array}{c}\text { Respondent } \\
\text { number }\end{array}$ & Score & Percentage (\%) & Category \\
\hline 1 & 10 & 71.43 & Sufficient \\
\hline 2 & 9 & 64.29 & Sufficient \\
\hline 3 & 10 & 71.43 & Sufficient \\
\hline 4 & 9 & 64.29 & Sufficient \\
\hline 5 & 10 & 71.43 & Sufficient \\
\hline 6 & 12 & 85.71 & Sufficient \\
\hline 7 & 9 & 64.29 & Sufficient \\
\hline 8 & 11 & 78.57 & Fair \\
\hline 9 & 7 & 50 & Poor \\
\hline 10 & 9 & 64.29 & Sufficient \\
\hline 11 & 11 & 78.57 & Fair \\
\hline 12 & 10 & 71.43 & Sufficient \\
\hline 13 & 9 & 64.29 & Sufficient \\
\hline 14 & 7 & 50 & Poor \\
\hline 15 & 10 & 71.43 & Sufficient \\
\hline 16 & 8 & 57.14 & Sufficient \\
\hline 17 & 9 & 64.29 & Sufficient \\
\hline 18 & 10 & 71.43 & Sufficient \\
\hline 19 & 11 & 78.57 & Fair \\
\hline 20 & 11 & 78,57 & Fair \\
\hline \multirow[t]{2}{*}{21} & 13 & 92.86 & Fair \\
\hline & Mean Result & 69.73 & Sufficient \\
\hline
\end{tabular}


palsy and epilepsy (Table 4). All subjects answered correctly on both questions about the needed teamwork between various elements in performing a fair dental health service for disabled children and counseling as one of the promotive ways in performing dental health service (Table 5 ).

The knowledge of the dentists in primary health service in Bandung City on oral health service for children with disability in primary service based on of The Indonesia's Health Minister's Regulation number 89 in 2015. The level of the dentists' knowledge are categorized into 3 levels, fair, sufficient, and poor (Table 6).

Six respondents ( $28.57 \%$ from the total) belong to fair category. This means that the dentists comprehend the characteristic and treatment for the disabled children. The majority of respondents (76.19\% from the total) show dsufficient category in treating the disabled children based on of The Indonesia's Health Minister's Regulation number 89 in 2015. This concludes that the dentists in primary service need additional information and knowledge on identifying children with disability. However, the sufficient category describes that the dentists know how to treat the disabled children but still lacking the knowledge to identify them.

\section{DISCUSSION}

Additional training for the dentists on treating the disabled children is strongly recommended. Furthermore, the sufficient level of knowledge in identifying children with disability is necessary as well. Based on the research, it can be concluded that the knowledge of dentists in Bandung City is sufficient according to the percentage shown from the table $(69.73 \%)$.

The research done by Dieguez-Perez ${ }^{10}$ showed that physically disabled children are prone to have poor oral hygiene which further leads to dental caries. Mentally disabled children have higher tendency to have gingival inflammation and deep gingival pocket. ${ }^{10}$ Mochizuki ${ }^{11}$ _research that was executed in year of 2007 suggested a routine plaque control for children with disability. Preventive and curative efforts are necessary regarding the fact that disabled children have higher level of poor oral hygiene than the normal children. ${ }^{11}$
The good knowledge of the dentists on identifying, characterizing, and treating disabled children is an absolute importance. It has been shown from the research result that the dentists still need additional training to improve the knowledge. The percentage of $38.10 \%$ of the dentists in primary service in Bandung City incorrectly defined the children with disability and $28.57 \%$ of them incorrectly answered the question about physical and mental disability of children.

The high score of the category of fair knowledge shown from the table describes that the dentists know and understand well the characteristic and treatment for the disabled children. However, the sufficient category shows that the dentists in primary health center need additional information and knowledge to identify the children with disability. The disabled children oral health treatment has been written in Ministry of Health Republic of Indonesia Regulation No. 89 year 2015 in accordance to oral health efforts. The efforts are in preventive, promotive, and curative ways.

\section{CONCLUSION}

Based on the research, it can be concluded that the dentists' knowledge on the oral health service of children with disability in primary health service based on Ministry of Health Republic of Indonesia Regulation No. 89 year 2015 is sufficient regarding the percentage of $69.73 \%$. This category describes the knowledge of the dentists in treating the disabled children is considered fair but is still weak, seeing from the fact that the dentists do not have sufficient knowledge to identify the disabled children.

\section{REFERENCES}

1. Ministry of Health Republic of Indonesia. Peraturan Menteri Kesehatan Republik Indonesia No. 89 Tahun 2015 tentang upaya kesehatan gigi dan mulut. Jakarta: Ministry of Health Republic of Indonesia; 2015. p. 12-3, 171-9.

2. Titien I. Peran dokter gigi dalam tumbuh kembang anak berkebutuhan khusus. Majalah Kedokteran Gigi 2012;19(2):176-80.

3. Mcdonald RF, Avery DR. Dentistry for the child and adolescent. St. Louis: Mosby; 1994. p. 592-3. 
4. Mitsea AG, Karidis AG, Donta-Bakoyianni C, Spyropoulos ND. Oral health status in Greek children and teenagers, with disabilities. J Clin Pediatr Dent 2001;26(1):111-8.

5. Al-Maweri SA, Zimmer S. Oral health survey of 6-14-year-old children with disabilities attending special schools Yemen. J Clin Pediat Dentist 2015;39:272-6.

6. Indahwati V, MantikMFJ, Gunawan PN. Perbandingan status kebersihan gigi dan mulut pada anak berkebutuhan khusus SLB-B dan SLB-C Kota Tomohon. J e-GIGI (eG) 2015;3:361-6.

7. Finn SB. Clinical pedodontics. $4^{\text {th }}$ ed. Philadelphia: W.B. Saunders Co.; 2003. p. 562-3.

8. Dewanto I. Penetapan dokter gigi layanan primer di Indonesia. Yogyakarta: Fakultas Ilmu
Kesehatan dan Kedokteran Universitas Muhammadyah Yogyakarta 2014;21:109-16.

9. Sastroasmoro S, Sofyan I. Dasar-dasar metodologi penelitian klinis. $4^{\text {th }}$ ed. Jakarta: Sagung Seto; 2011. p. 98.

10. Dieguez-Perez M, de Nova-Garcia MJ, Mourelle-Martinez MR, Bartolome-Villar B. Oral health in children with physical (cerebral palsy) and intellectual (down syndrome) disabilities: systematic review i. J Clin Exp Dent 2016;8(3):e337-e343.

11. Mochizuki K, Tsujino K, Ohtawa Y, Yakushiji $M$, Nomura K, Ichinohe $T$, et al. Dental care for physically or mentally challenged at public dental clinics. Bull Tokyo Dent Coll 2007;48(3):135-42. 